\title{
ИНСТРУМЕНТЫ ГРАЖДАНСКОГО ВОЗДЕЙСТВИЯ НА РАЗВИТИЕ ПУБЛИЧНОЙ СЛУЖБЫ В УКРАИНЕ КАК ФАКТОР ГУМАНИЗАЦИИ УКРАИНСКОГО ОБЩЕСТВА
}

\begin{abstract}
В статье рассматриваются инструменты общественного воздействия на развитие публичной службы в Украине как фактор гуманизации украинского общества. Проанализирован уровень активности современного гражданского общества в Украине, в том и числе его трансформация в процессе социально-политических изменений в стране. Проведен анализ подходов к пониманию общественного влияния на формирование публичной службы в Украине. Раскрыто понятие «общественного контроля за принятием государственно-управленческих решений». Рассмотрены инструменты общественного влияния на формирование государственноуправленческих решений - консультативно-согласовательные советы, гражданский контроль, лоббирование.

Показан процесс становления института консультативно-совещательных советов с учетом опыта подготовки и принятия нормативно-правовых документов, регламентирующих их деятельность, без согласования с общественностью. Прописано значение гражданской экспертизы для оценки деятельности органов исполнительной власти, целесообразности принятия и выполнения такими органами решений, подготовки ими проектов нормативно-правовых актов по правам и свободам человека, кругу полномочий органов публичной власти и должностных лиц.

Исследованы и установлены характерные отличия гражданского контроля от других видов контроля. Отмечено, что в условиях построения в Украине демократического, социального, правового государства гражданский контроль является неотъемлемой составляющей системы демократического публичного управления, незаменимой константой развития общества, обеспечивающего
\end{abstract}

\footnotetext{
${ }^{1}$ Ольга Антонова кандидат наук по государственному управлению, доцент, ученый секретарь, доцент кафедры государственного управления и местного самоуправления Днепропетровский региональный институт государственного управления Национальной академии государственного управления при Президенте Украины, Украина, 49044, г. Днепропетровск, ул. Гоголя, 29, к. 215, o.v.antonova@vidr.dp.ua, max-antonova@gmail.com

2 Виктория Климович заместитель начальника отдела дистанционного обучения и информатизации управления по учебной и методической работе, магистр государственного управления, Днепропетровский региональный институт государственного управления Национальной академии государственного управления при Президенте Украины

3 Елена Самбук ведущий специалист отдела координации, маркетинга и мониторинга научных исследований управления по научной работе, магистр государственного управления, Днепропетровский региональный институт государственного управления Национальной академии государственного управления при Президенте Украины
} 
поддержку властно-общественных отношений в состоянии стабильности и равновесия.

Ключевые слова: инструменты гражданского воздействия, развитие публичной службы, гуманизация системы государственного управления, гражданский контроль, разработка государственной политики и принятие государственно-управленческих решений

\section{1. ВВЕДЕНИЕ}

Действующая в Украине система государственного управления, построенная на традициях управления советской эпохи и сформированная спецификой постсоветской ментальности на этапе становления рыночной экономики, накопления первичного капитала, обусловила появление проблем с интерпретацией роли представителей власти в социальном управлении. В восприятии граждан нынешняя государственная власть ассоциируется с тотальной коррупцией, правовым нигилизмом и непотизмом, силовыми и нелегальными способами добычи ресурсов, благ и льгот. Неэффективность воздействия объединенных общественных усилий «простых людей» (в том числе и представителей гражданского общества) на положение дел в стране до сих пор обусловлена низким уровнем ответственности за судьбу страны в списке личных достоинств не только обычных украинцев, но и управленцев, работников бюджетной сферы, и особенно политиков. Материальное обеспечение этих социальных групп покрывается и охватывается таким понятием как «бедность работающего населения» и уровнем физиологического выживания (согласно уровням потребностей пирамиды Маслоу А.) работающих на громаду и государство бюджетников. Фактически следует говорить о формировании профессиональной среды (бюджетная сфера, распределительная политика бюджетных средств) для получения неправомерной выгоды, позволяющей подняться еще на один-два уровня удовлетворения потребностей.

В результате событий 2014 - 2015 гг. в Украине открылось «окно возможностей», которое стало импульсом к качественным изменениям государственного аппарата, общества, местных громад, гражданского общества и граждан в целом. Чтобы использовать эти возможности в полном объеме необходимо комплексное обновление государственной власти путем восстановления доверия в обществе, гражданского доверия политическим институтам и государству. Таким образом, государственная служба должна быть представлена людьми, связывающими свое будущее (в том числе и профессиональное) и безопасность будущих поколений с Украиной, стремящимися к более высокому уровню, качеству жизни, способу, ориентирующимися не на прошлое, а на будущее. Речь идет о сосуществовании и создании благоприятных условий для всех, в объемах равных как для социальных групп, так и для граждан, как в правах, так и в обязанностях. Особенно актуальна эта проблематика в контексте продолжения дискуссии о важности понятия «публичное управление», предложенной доктором М. К. Юргилевич, доктором О. Юргилевич, доктором М. Ура в статье «Несколько ремарок по поводу значения понятия публичного управления» ${ }^{4}$.

\footnotetext{
${ }^{4}$ M.K. Jurgilewicz, O. Jurgilewicz, M. Ura, Kilka uwag na temat znaczenia pojęcia administracji publicznej,
} „Modern Management Review” 21/2 (2014), p. 43-52. 


\section{2. АКТУАЛЬНОСТЬ ТЕМЫ И ПОСТАНОВКА ЦЕЛИ СТАТЬИ}

Современная реальность в Украине свидетельствует об огромном перекосе или разрыве в оценке распределения объемов соотношения прав и обязанностей между государством и его гражданами. Имея права, граждане и гражданское общество не в состоянии их реализовать, поскольку механизмы и структуры их обеспечивающие, работают по принципу первичного накопления капитала. И удовлетворение базовых потребностей в основном сводится к минимальной потребительской корзине (так называемая корзина «выживания») без обеспечения безопасности и в отсутствие гарантий достижения определенного социального статуса легальным путем. Олицетворение власти или слияние с государственной должностью происходит с пониманием важности управления распределительной политикой, управлением денежными потоками, соответственно приобретением дополнительных ресурсов и благ, не обеспеченных официальными зарплатами. Именно таким образом происходит перекос в объеме выполнения гражданских обязанностей перед государством (налоги, «открытая» финансовая отчетность бизнеса, соблюдение законов) и прав, которые «по закону» реализовать не представляется возможным. В нынешних обстоятельствах принцип справедливости и баланса в социальных отношениях, бережно поддерживаемый системами государственной службы в любой стране, в Украине нарушен в самой основе - принципах существования государственной службы.

Не менее печальная ситуация складывается и в службе в органах местного самоуправления. Речь идет о формальных изменениях в правовом статусе (ужесточении мер ответственности), социальной защите (её сокращении), а не о функциональном наполнении службы - службы на благо громад и их развитие. Реформа децентрализации касается перераспределения объемов полномочий, которые не подтверждены децентрализацией управления финансовыми ресурсами, несамостоятельностью и несостоятельностью местных элит в формировании и проведении политики общественного и гражданского диалога.

Современное научное сообщество признает, что в Украине управленческая элита слишком политизирована, поэтому состояние формирования для неё приобретает хронический характер. Элита не только не стабильна, но и пребывание в ней становится своего рода коммерческим проектом, ограниченным по срокам избирательным законодательством. Звено основных исполнителей и руководителей средней категории остаются в основе неизменным составом. Статистические данные по государственным служащим за последние пять лет, приведенные Национальным агентством Украины по вопросам государственной службы, убедительно служат ещё одним доказательством повышения среднего возраста основного исполнителя функций государства. Так, по состоянию на 01 января 2015 г. на государственной службе и службе в органах местного самоуправления в Украине пребывают 380 тыс. чел. ${ }^{5}$, из них:

- 25\% мужчины и 75\% женщины;

- руководители $26,3 \%$ и специалисты $73,72 \%$;

\footnotetext{
${ }^{5}$ Державна служба в иифрах - 2015: Інформаџійне видання Центру адаптації державної служби до стандартів $\quad \epsilon C, \quad$ Прес-центр, http://www.center.gov.ua/pres-tsentr/materiali/item/135686\%D0\%B8\%D1\%84\%D1\%80\%D0\%B0\%D1\%85-2013.
} 
- до 35 лет (государственная служба - 46,7\% женщины и 43\% мужчины; служба в органах местного самоуправления - 27,2 женщины и $21,7 \%$ мужчины);

- 36-59 лет (государственная служба - 53,2\% женщины и 54,8\% мужчины; служба в органах местного самоуправления - 71,3 женщины и 75,4\% мужчины).

И по формальным признакам причина неэффективности государственного аппарата находится не в этом факте, а в сознательном организационном сопротивлении непоследовательным, фрагментарным и нелогичным изменениям и новшествам, начиная от освоения IT-технологий до новых методов работы, инициированным очередной сменой политических реформаторов.

Большинство решившихся прийти на государственную службу молодых управленцев переживают кризис некомпетентности и разочарования от неоправдавшихся «идеальных» ожиданий, который им приходится преодолевать в процессе работы. В это же время в деловом секторе Украины медленно, но происходит постоянное самосовершенствование, «стимулируют» конкуренты, привлекаются современные технологии управления человеческими ресурсами, управления персоналом, происходит переориентация деятельности на стандарты Европейских Сообществ. В государственных и бюджетных структурах происходит системное и комплексное сдерживание «старожилами системы» - рядовыми исполнителями, руководителями среднего и низшего звена, которые «пересидели» многих политических руководителей и, по сути, олицетворяют собой и систему власти, и механизм её осуществления в современной ситуации.

Бесперспективность проведения реформ на протяжении более 20 лет независимости Украины актуализировала доминирование этого подхода в вопросах «выживания», в том числе и профессионального. Уровень выживания кадров в государственном аппарате очень показателен. И, по нашему мнению, этот факт не является основным негативным фактором, который тормозит реформы в Украине. Как раз наоборот, опыт и видение многих политических попыток привнести структурные изменения следовало б поручить именно профессионалам-старожилам, которые видят системные проблемы, разрывы и при этом всю свою жизнь посвящают государственной службе.

Учитывая выше описанное, молодые специалисты редко связывают свою жизнь, профессиональную стратегию с государственной службой. Они рассматривают её скорее как «трамплин» для бизнес-карьеры или как источник «полезных связей». При этом государственные структуры тоже не ищут таланты, поскольку, кроме минимальных размеров заработной платы и «вечной» лояльности системе, им предложить молодым талантам просто нечего, включая и моральнопсихологический климат «старожилов», и условия труда в целом.

История с созданием механизмов «социальных лифтов», связанных со службой на благо общества и государства корнями своими уходит в прошлое советской номенклатуры. По нашему мнению, это - добротный механизм кадрового замещения, механизм обновления управленческих кадров на государственной службе. В Украине, к огромному сожалению, система «социальных лифтов» через занятие должности государственной службы или служение на благо громады полностью разрушена. На смену ей пришла новая проектная технология по созданию политических партий и работе команд политических лидеров, обеспечивающих их деятельность в государственном аппарате за счет бюджетных средств. 
Так называемая «команда лидера» представляет собой доверенных лиц, проверенных временем, общими делами, иногда родственными связями. Это привело к тому, что в Украине нарушены процедуры «карьерного лифта», а именно: прохождения всех уровней управленческой лестницы - от нижнего до верхнего. Хотя изначально знание системы управленческих процедур необходимо для того, чтобы руководитель имел четкое представление, как функционирует система, в которой он работает, как она «вписывается» в другие системы и институты общества, каковы принципы взаимодействия структуры и общества, а также какими могут быть последствия принятого или непринятого государственноуправленческого решения. Вышеуказанные факторы формируют «культуру временщиков» у власти и оперативно-ситуационное управление вне идеологических платформ.

Масштабная переоценка ценностей, освобождение общественного сознания от давления идеологических шаблонов актуализируют приоритетность подготовки профессионалов в сфере публичного управления (исключительно администрирования), владеющих широкими гражданскими компетентностями. Вместе с тем уровень квалификации государственных служащих, как отмечает Ничта Н.Л., в целом отстает от постоянно растущего уровня сложности управленческих задач ${ }^{6}$. А система конкурсного отбора и практически отсутствие мотивации к профессиональному совершенствованию не содействуют выявлению и привлечению лучших специалистов «профессионал - гражданин», накоплению потенциала в государственно-управленческой сфере.

Таким образом, целью статьи является анализ действующих в Украине механизмов организованного гражданского влияния на развитие публичной службы в контексте гуманизации украинского общества, а также разработка инструментов гражданского воздействия на становление публичной службы в Украине в аспекте приближения принципов её деятельности к сути гражданских прав и свобод, содействие их реализации.

\section{3. АНАЛИЗ ПОДХОДОВ ОБЩЕСТВЕННОГО ВЛИЯНИЯ НА ФОРМИРОВАНИЕ ПУБЛИЧНОЙ СЛУЖБЫ В УКРАИНЕ}

Идее развития интегрированного института публичной службы в Украине в контексте социально-экономических реформ посвящены работы Петренко О.С. 7 , Серегина C.M. ${ }^{8}$, Баштанника B.B. ${ }^{9}$, Гончарук H.T. ${ }^{10}$, Хожило И.И.. ${ }^{11}$, Липовской

\footnotetext{
6 Н.Л. Ничта, Психологічний ресурс оптимізаиії взаємодії місчевих органів виконавчої влади $з$ громадськістю: автореф, дис. ... канд.. наук з держ.упр. 25.00.02, Нац. акад. держ. упр. при Президентові України, Львів. регіон. ін-т держ. упр., Львів 2014.

${ }^{7}$ Морально-етичні засади розвитку державної служби Украйни: європейський та вітчизняний досвід: монографія, С.М. Серьогін, О.В. Антонова, І.І. Хожило та ін..; за заг. ред. проф. С.М. Серьогіна. ДРІДУ НАДУ, Д. 2007; О.С. Петренко, Формування інтегрованого інституту публічної служби в Україні, автореф. дис. к-та наук з держ. упр. 25.00.03, Петренко О.С.; ДРІДУ НАДУ при Президентові України, Д. 2008; Синергетичні засади державного управління в умовах реформ: монографія, С.М. Серьогін, I.В. Письменний, І.І. Хожило та ін.; за заг. ред. С.М. Серьогіна, ДРІДУ НАДУ, Д. 2007.

${ }^{8}$ Морально-етичні засади розвитку...; Реформування професійного навчання державних службовців в Україні: проблеми та перспективи, ДРІДУ НАДУ.: колект. моногр., С.М. Серьогін, Є.І. Бородін, Н.А. Липовська, І.І. Хожило та ін.; за заг. та наук. ред. С.М. Серьогін, ДРІДУ НАДУ, Д 2012; Синергетичні
} 
H.А. ${ }^{12}$, Василевской Т.Э. ${ }^{13}$ как в аспекте развития государственной службы с административным предназначением, так и специализированной. Отдельно предлагалось введение института службы местного самоуправления и института службы с политическим назначением. Вопросам профессионализации государственной службы и службы в органах местного самоуправления, развитию публичной службы в целом посвящены исследования Артеменко Н.Ф. ${ }^{14}$, Газарян C.В. ${ }^{15}$, Кошевой T.В. ${ }^{16}$, Крутий О.Н. ${ }^{17}$, Кушнировой Г.П. ${ }^{18}$, Нинюк И.И. ${ }^{19}$, Пархоменко-Куцевил О.И. ${ }^{20}$, Сидоренко Н.С. ${ }^{21}$, Филиповой Т.В. ${ }^{22}$, Цегольник П.А. ${ }^{23}$, Шпекторенко I.B. ${ }^{24}$. Все выше перечисленное свидетельствует о попытках отечественного научного сообщества в сфере государственного управления привлечь внимание и заложить основы эволюционного системного продвижения изменений государственного аппарата. Несмотря на профильную разработанность темы и выход фундаментальных изданий в сфере государственного управления и

засади державного управління в умовах реформ: монографія, С.М. Серьогін, І.В. Письменний, I.I. Хожило та ін.; за заг. ред. С.М. Серьогіна, ДРІДУ НАДУ, Д. 2007.

${ }^{9}$ В.В. Баштанник, Трансформачія державного управління в контексті європейських інтеграційних проиесів: монографія, ДРІДУ НАДУ, Д. 2010; Морально-етичні засади розвитку...

${ }^{10}$ Н.Т. Гончарук, Управління керівним персоналом у сфері державної служби Украӥни: теорія та практика: монографія, ДРІДУ НАДУ, Д. 2012; Морально-етичні засади розвитку...

${ }^{11}$ Морально-етичні засади розвитку...; Реформування професійного навчання...; Синергетичні засади державного...

${ }^{12}$ Морально-етичні засади розвитку...; Реформування професійного навчання...; Синергетичні засади державного..

13 Т.Е. Василевська, Етичні виміри громадянськості державного службовия, „Публічне управління: теорія та практика" 1/5 (2011), http://www.kbuapa.kharkov.ua/e-book/putp/2011-1/doc/3/05.pdf.

${ }^{14}$ Н.Ф. Артеменко, Управління професіоналізацією кадрів державної служби України, автореф. дис. к-та наук з держ. упр., 25.00.03, ДРІДУ НАДУ при Президентові України, Д. 2010, 23 с.

${ }^{15}$ С.В. Газарян, Професіоналізаиія служби в органах місиевого самоврядування: зміст, форми та методи, автореф. дис. д-ра наук з держ. упр., 25.00.03, НАДУ при Президентові України, К. 2011, 39 с.

${ }^{16}$ Т.В. Кошова, Професійний розвиток державних службовиів на засадах самотренінгу, автореф. дис. кта наук $з$ держ. упр., 25.00.03, ДРІДУ НАДУ при Президентові України, Д. 2004, 22 с.

17 О.М. Крутій, Діалогова взаємодія органів влади та громадськості як умова демократизації державного управління, автореф. дис. ... д-ра наук з держ.упр., 25.00.02, Нац. акад. держ. упр. при Президентові України, Харк. регіон. ін-т держ. упр., Х. 2010, 36 с.

${ }^{18}$ Г.П. Кушнірова, Формування професійної компетентності посадових осіб місиевого самоврядування, автореф. дис. к-та наук з держ. упр., 25.00.03, НАДУ при Президентові України, К. 2011, 23 с.

19 I.I. Нинюк, Професіоналізм держсавних службовиів: сутність, стан та особливості формування, автореф. дис. к-та наук з держ. упр., 25.00.03, НАДУ при Президентові України, К. 2005, 18 с.

${ }^{20}$ O.I. Пархоменко-Куцевіл, Формування, розвиток та модернізація державних посад: концептуальнометодологічні засади: монографія, ФАДА, ЛТД, К. 2010, 296 с.

${ }^{21}$ Н.С. Сидоренко, Формування професійної культури державних службовців, автореф. дис. к-та наук $з$ держ. упр., 25.00.03, НАДУ при Президентові України, К. 2012, 23 с.

22 Т.В. Філіпова, Професійний менталітет державних службовиів в Украйні: технологія формування, автореф. дис. к-та наук з держ. упр., 25.00.03, ДРІДУ НАДУ при Президентові України, Д. 2006, 20 с.

${ }^{23}$ П.А. Цегольник, Формування професійної моделі фахівия в сфері управління, автореф. дис. к-та наук 3 держ. упр., 25.00.03, НАДУ при Президентові України, К. 1997, 17 с.

${ }^{24}$ І.В. Шпекторенко, Управління професійною мобільністю державних службовиів, автореф. дис. д-ра наук $з$ держ. упр., 25.00.03, Інститут 3-тва Верховної Ради України, К. 2012, 32 с. 
государственной службы ${ }^{25}$, выявилась необходимость в привлечения внимания исследователей к гражданской социализации и развитии, поддержке гражданской компетентности государственных служащих, служащих в органах местного самоуправления.

Радикальный разворот публичной службы в сторону гражданина, защиты его прав и интересов ${ }^{26}$, обуславливает его роль в обществе не как просителя, а как «клиента» государственного учреждения, реализующего свои права как потребителя услуг, предоставляемых ему государством, и оплачиваемых им как налогоплательщиком. Таким образом, взаимодействие между органами власти и управления, с одной стороны, и институтами гражданского общества, средствами массовой информации, гражданами - с другой, содействует развитию механизмов гражданского участия в принятии и реализации управленческих решений. А также способствует формированию и продвижению имиджа государственной и службы в органах местного самоуправления как открытых систем, доступных для граждан и им понятных. Формирование современной публичной службы, способной справляться с вызовами сложных ситуаций, становится возможным благодаря гражданскому самосознанию всего общества, а не отдельно взятых социальных групп. Как раз это, по мнению Лукашевич О.М., проявляется в принципиальной позиции личности гражданина по отношению к событиям и явлениям, происходящим в общественной жизни и в системе государственного управления ${ }^{27}$.

Деятельность государственных институтов постоянно тестируется гражданами именно по критерию «прислушивания» к мнению общества, а не только отдельных социальных групп. В период Революции достоинства и знаковых политических событий, которые продолжают происходить в Украине и сейчас, такое тестирование приобрело четкие и выразительные черты гражданской активности в системном режиме, когда от власти требуется открытость, ответственность, справедливость в решениях.

Общечеловеческое свойство к сочувствию и способность интегрироваться вокруг идеи отстаивания прав объединяет усилия граждан и приобретает ценность как инструмент воздействия гражданского общества на формирование государственных решений, на выбор способа принятия и доведения управленческих решений до реализации (авторитарный, демократический, либеральный, партисипативный и др.). Формирование государственных институтов на сегодняшний день находится под сильным доминирующим политическим воздействием, что не может не отражаться на становлении публичной службы в её европейской интерпретации и ориентации на открытость, доступность, прозрачность управленческих процедур и механизмов, подотчетность и так далее.

${ }^{25}$ Енииклопедичний словник з держсавного управління, уклад. Ю.П. Сурмін, В.Д. Бакуменко, А.М. Михненко та ін.; за ред. Ю.В. Ковбасюка, В.П. Трощинського, Ю.П. Сурміна, НАДУ при Президентові України, К. 2010, 820 с.; Енциклопедія державного управління, у 8 т., Нац. акад. держ.упр. при Президентові України, наук. ред. колегія Ю.В. Ковбасюк (голова) та ін., К. 2011.

${ }^{26}$ Конституція України: прийнята на п’ятій сесії Верховної Ради України 28 черв. 1996 р., зі змінами згідно Закону України від 21 лютого 2014/742, Відомості Верховної Ради України, К. 2014/11, с. 143; Стратегія сталого розвитку «Україна - 2020», Указ Президента України від 12 січня 2015 р., 2015/5, http://www.president.gov.ua/documents/18688.html.

${ }^{27}$ О.М. Лукашевич, Громадянськість як результат..., с. 467-477. 
Демократизация общественно-политических процессов создает «эффект аквариума». Когда ко всем сферам жизнедеятельности политического деятеля, должностного лица центрального уровня, государственного служащего регионального и местного уровня приковано внимание людей: от деклараций про доходы и вплоть до его личной жизни именно как публичного лица, представителя интересов граждан, результаты деятельности которого могут иметь последствия, влияющие на жизнь будущих поколений граждан. Стоит заметить, что все эти требования к государственным служащим Украины четко описаны рядом нормативно-правовых документов таких, как: Общие правила поведения государственного служащего, утвержденные приказом Главным управлением государственной службы в 2009 г. и Постановлением Кабинета Министров Украины в 2016 г.; Закон Украины «О государственной службе» (2015), Закон Украины «О предотвращении коррупции» (2014), в котором предусмотрена уголовная ответственность за коррупционные действия и др. И при этом ни один из документов не имел позитивных последствий в борьбе за добросовестность исполнения службы.

Подобная ситуация сложилась и с присягой. Присяга государственного служащего, присяга служащего в органах местного самоуправления, присяга военнослужащего, присяга судьи, которые дают и подписывают вступающие на государственные должности, не являются залогом верности её основным идеям в условиях выживания. И об этом свидетельствует множество нормативно-правовых документов, связанных с процессами люстрации, и особенно нарушения присяги на верность государству и принципам службы.

Вместе с тем формирование позитивного образа государственного служащего не может быть успешным, если его должностные обязанности не будут подкреплены обязанностями государства по обеспечению его правовой защиты, надлежащих условий труда и достойного уровня жизни. Не менее важной есть правовая защита от преследований за выявление фактов нарушения закона, злоупотребления властью или фактов коррупции, которая давно и успешно действует на территории современных демократических государств - Соединенных Штатов Америки, Канаде, Великой Британии, Франции, Швейцарии, Бельгии, Австрии. В этих странах подобные действия считаются гражданским долгом во благо общества. Таким образом, формирование и развитие публичной службы в условиях повышения уровня гражданственности в обществе должно проходить в двух направлениях: создания системы (само-)мотивации, повышения профессиональной, гражданственной ответственности за добросовестность выполнения службы. Содействовать последнему как раз и призван один из действенных механизмов общественный контроль над принятием управленческих решений.

\section{4. ОБЩЕСТВЕННЫЙ КОНТРОЛЬ НАД ПРИНЯТИЕМ УПРАВЛЕНЧЕС- КИХ РЕШЕНИЙ}

Объединение разрозненного влияния общественных групп на принятие решений и контроля над деятельностью власти требует повышения уровня гражданской вовлеченности в эти процессы. Успешным общественное участие в формировании и реализации государственно-управленческих решений может считаться, когда проблемы, озвученные общественностью, начинают решаться органами власти. 
Общественное участие не может происходить само по себе - это запланированное усилие по привлечению граждан в процесс принятия решений ${ }^{28}$.

Доверие - одно из ключевых понятий теорий демократии и рынка. В общественной жизни доверие содействует объединению общественности и созданию обществ, а в экономической сфере оно ускоряет сотрудничество и межличностный обмен. Доверие основывается на убежденности граждан в том, что политические институты будут эффективно решать вопросы даже при отсутствии контроля над их деятельностью. Гражданское доверие правительству формируется тогда, когда политика правительства направлена на соответствие и удовлетворение интересов граждан. Таким образом, гражданское доверие выступает следствием функционирования политических институтов ${ }^{29}$. Следует отметить, что демократическая активность и наличие гражданских свобод содействуют росту уровня политической толерантности в обществе ${ }^{30}$.

Для понимания природы социально-политических процессов, имеющих место в Украине, важно провести анализ динамики доверия политическим и социальным институтам на протяжении всего «европейского» периода независимости Украины - с 2004 по 2015 годы. Примечательно, что украинцев все больше заботят проблемы не только собственного экономического благополучия, а и состояние страны в целом, и негативные экономические и политические тенденции, которые фиксируют СМИ, приводят к падению уровня доверия к руководителям страны ${ }^{31}$.

28 Ефективна організачія роботи громадської ради: методичні рекомендаиії, www.gromrady.org.ua/2011/06/posibnyk-efektyvna-orhanizatsiya-roboty-hromadskoji-rady-metodychnirekomendatsiji.

${ }^{29}$ K. Newton, Political trust and institutional performance, Social and Political Trust, European Social Survey, 2013, http://essedunet.nsd.uib.no/cms/topics/2/3/all.html.

${ }^{30}$ M. Peffley, Democratization and Political Tolerance in Seventeen Countries: A Multi-level Model of Democratic Learning, M.Peffley, R.Rohrchneider, „Political Research Quarterly” 56/3 (2003), c. $243-257$.

${ }^{31}$ Українське суспільство 1992-2012. Стан та динаміка змін. Соиіологічний моніторинг, За ред. д. ек. н. В. Ворони, д. соц. н. М. Шульги., Інститут соціології НАН України, К. 2012, 660 c, http://isoc.com.ua/institute/soc-mon-2012.pdf; Моніторинг громадської думки, Український інститут соціологічних досліджень ім. О.Яременка, http://www.uisr.org.ua/monitoring; Довіра до сочіальних інституцій та групп: за матеріалами прес-релізу Ліана Новіковой (по состоянию на 4-14 декабря 2015), Київський міжнародний сінститут соціології, http://www.kiis.com.ua/?lang=ukr\&cat=reports\&id=579\&page=2\&t=3; Довіра до політичних інститутів та банків падає, компанії повертають довіру громадян (GfK Ukraine), http://sostav.ua/news/2009/04/22/8/19934/ 


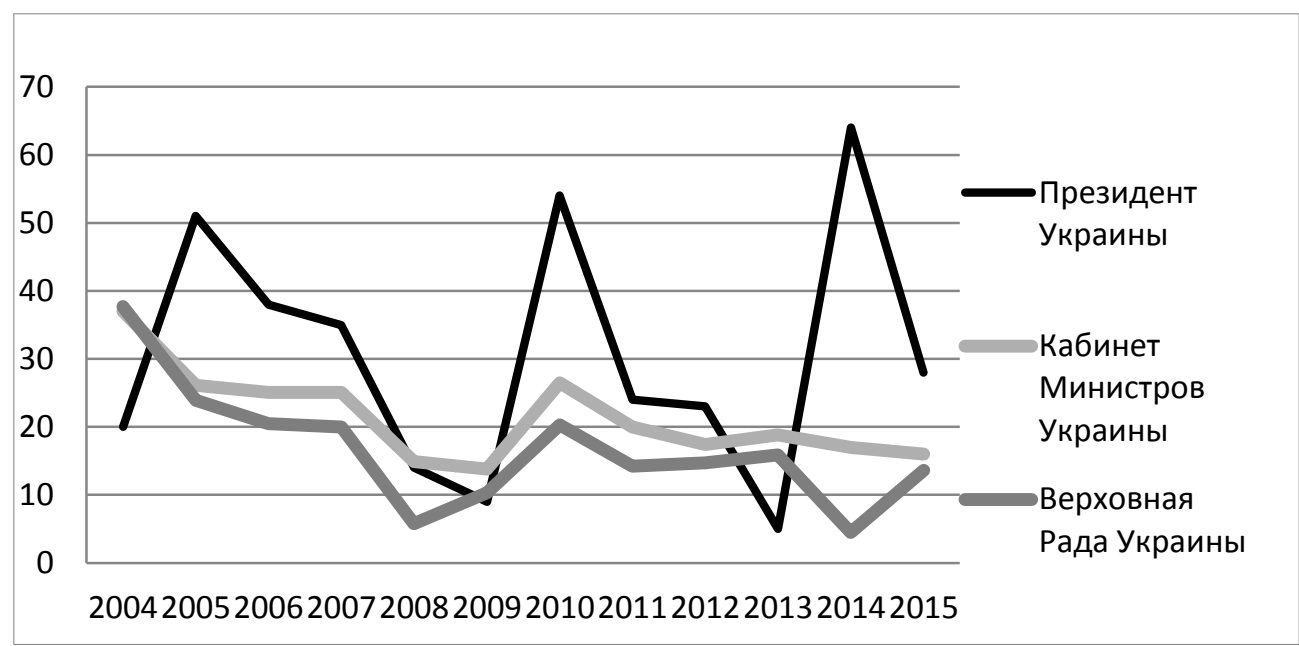

Рис. 1. Динамика изменений уровня доверия Президенту Украины, Кабинету Министров Украины, Верховной Раде Украины с 2004 по 2015 гг.

Таким образом, доверие в условиях неопределенности связано с общественными ожиданиями определенных решений от субъектов власти. В то же время демократичность политического развития, среди признаков которой - минимизация уровня коррупции в обществе, создание условий для прозрачности, открытости функционирования органов государственной власти, предоставление возможности гражданам быть участниками процесса принятия решений в сфере государственной политики, будет содействовать повышению уровня доверия к политическим институтам как субъектам реализации общественных интересов ${ }^{32}$.

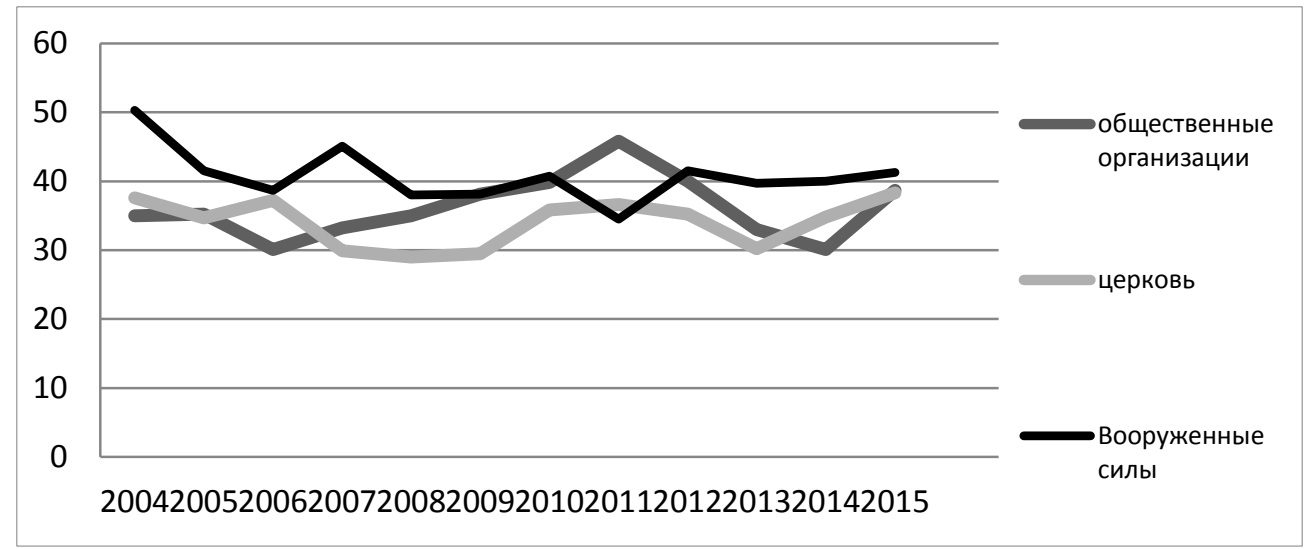

Рис. 2. Динамика изменений уровня доверия общественным организациям, церкви и Вооруженным Силам Украины с 2004 по 2015 гг.

\footnotetext{
${ }^{32}$ М.В. Чабанна, Довіра до політичних інститутів: передумови та наслідки для демократії, Магістеріум, К. 2014, Вип. 58, с. 8-14.
} 
Инструменты гражданского воздействия...

Таблица 1. Сравнительная таблица динамики изменений уровня доверия Президенту Украины, Кабинету Министров Украины, Верховной Ради Украины общественным организациям, церкви и Вооруженным Силам Украины с 2004 по 2015 гг.

\begin{tabular}{|c|c|c|c|c|c|c|}
\hline & Президент & $\begin{array}{c}\text { Кабинет } \\
\text { Министров }\end{array}$ & $\begin{array}{c}\text { Верховная } \\
\text { Рада }\end{array}$ & $\begin{array}{c}\text { Общественные } \\
\text { организации }\end{array}$ & Церковь & Армия \\
\hline $\mathbf{2 0 0 4}$ & 20 & 37 & 37,7 & 35 & 37,6 & 50,3 \\
\hline $\mathbf{2 0 0 5}$ & 51 & 26,1 & 23,9 & 35,2 & 34,7 & 41,5 \\
\hline $\mathbf{2 0 0 6}$ & 38 & 25,1 & 20,5 & 30,1 & 37,2 & 38,7 \\
\hline $\mathbf{2 0 0 7}$ & 35 & 25,1 & 20 & 33,2 & 29,9 & 45,1 \\
\hline $\mathbf{2 0 0 8}$ & 14 & 14,9 & 5,8 & 35, & 29 & 38 \\
\hline $\mathbf{2 0 0 9}$ & 9 & 13,8 & 10,3 & 38,1 & 29,5 & 38,1 \\
\hline $\mathbf{2 0 1 0}$ & 54 & 26,5 & 20,3 & 39,8 & 35,8 & 40,7 \\
\hline $\mathbf{2 0 1 1}$ & 24 & 20 & 14,2 & 45,8 & 36,6 & 34,5 \\
\hline $\mathbf{2 0 1 2}$ & 23 & 17,4 & 14,7 & 40 & 35,2 & 41,5 \\
\hline $\mathbf{2 0 1 3}$ & 19,3 & 18,8 & 15,9 & 33 & 30,2 & 39,7 \\
\hline $\mathbf{2 0 1 4}$ & 64 & 17 & 4,5 & 30,1 & 34,8 & 40 \\
\hline $\mathbf{2 0 1 5}$ & 28 & 16 & 13,6 & 38,7 & 38,3 & 41,3 \\
\hline
\end{tabular}

В последние несколько лет уровень доверия населения украинским институтам власти уменьшается. Вместе с тем, институты, обеспечивающие функционирование и развитие государственной системы, могут эффективно действовать при условии, если сумма общественного доверия превышает необходимый минимум. Если доверие падает ниже критического уровня, при котором начинает доминировать недоверие, механизмы общественного управления и регулирования «пробуксовывают», их способность принимать действенные управленческие решения минимизируется ${ }^{33}$. Складывается ситуация существования двух параллельных монологов - «политической власти - государства» и «граждан общественных (гражданских) организаций», автономное существование которых отдаляет перспективу их диалога. Организация диалога между властью и гражданами является сложным процессом, однако его постоянное инициирование двумя сторонами будет стимулировать постепенное формирование общественного мнения об основных механизмах, формах и методах достижения политического консенсуса, социальной солидарности и интеграции в обществе ${ }^{34}$. Организованное формирование гражданского участия в разработке управленческих общественно значимых решений постепенно уходит в сферу внимания общественных и гражданских организаций.

На сегодняшний день в Украине существуют разные формы общественного воздействия на формирование государственно-управленческих решений. Среди них следует отметить консультативно-согласовательные органы (общественные советы), общественную экспертизу, общественный контроль, лоббирование. Эволюция организованного влияния на формирование государственноуправленческих решений представлена в таблице.

${ }^{33}$ О. Лісєєнко, Динаміка політичного капіталу в Украӥні, „Політичний менеджмент” 10/1 (2005), с. 90-96.

34 О. Кучабський, Довіра до органів публічної влади як ключовий фактор ефективності системи державного управління, О. Кучабський, С. Погорєлий, „Публічне управління: теорія та практика” 13/1 (2013), http://kbuapa.kharkov.ua/e-book/putp/2013-1/doc/2/07.pdf. 
Таблица 2. Эволюция развития форм общественного воздействия на формирование государственно-управленческих решений в Украине

\begin{tabular}{|c|c|c|c|c|}
\hline $\begin{array}{c}\text { Формы } \\
\text { общественного } \\
\text { воздействия }\end{array}$ & $\begin{array}{c}\text { Дата } \\
\text { созда- } \\
\text { ния }\end{array}$ & Функции & Миссия & Результат \\
\hline \multirow[t]{5}{*}{$\begin{array}{l}\text { Консультативно- } \\
\text { совещательные } \\
\text { органы } \\
\text { (общественные } \\
\text { советы) }\end{array}$} & 1993 & $\begin{array}{l}\text { Совет предпринимателей } \\
\text { Украины -консультативно- } \\
\text { экспертный орган при Кабинете } \\
\text { Министров Украины }\end{array}$ & $\begin{array}{l}\text { Информирование и взаимодействие } \\
\text { предпринимательских структур по } \\
\text { реализации государственной политики } \\
\text { развития предпринимательства и } \\
\text { формирования рыночной } \\
\text { инфраструктуры }\end{array}$ & \multirow[t]{2}{*}{$\begin{array}{l}\text { Донесение проблем и интересов, } \\
\text { активизация процесса формирования } \\
\text { сознательной и активной позиции } \\
\text { общественности по отношению к } \\
\text { дальнейшему развитию государственной } \\
\text { политики и поддержки общественных } \\
\text { инициатив }\end{array}$} \\
\hline & 1996 & $\begin{array}{l}\text { Общественный совет при } \\
\text { Министерстве экологии и } \\
\text { природных ресурсов Украины }\end{array}$ & $\begin{array}{l}\text { влияние на процессы принятия решений } \\
\text { по охране окружающей среды }\end{array}$ & \\
\hline & 2003 & $\begin{array}{l}\text { Всего - 16; } \\
\text { КМУ - 23 (реальних - 2); } \\
\text { при Президенте Украины - } 27 \\
\text { (реально работавших - 4); } \\
\text { Комитетах Верховной Рады } \\
\text { Украины - } 23 \text { (реально } \\
\text { работавших - 5) }\end{array}$ & $\begin{array}{l}\text { Эксперты - государственные служащие и } \\
\text { узкопрофильные специлисты. } \\
\mathbf{1} \text { тип - межведомственные комиссии } \\
\text { и/или рабочие группы из } \\
\text { государственных служащих; } \\
\mathbf{2} \text { тип - узкопрофильные специалисты }\end{array}$ & $\begin{array}{l}\text { Общие консультации и рекомендации для } \\
\text { учета в деятельности органов власти; } \\
\text { трансформация в общественные коллегии } \\
(2005)\end{array}$ \\
\hline & $\begin{array}{l}2006- \\
2009\end{array}$ & $\begin{array}{l}\text { при центральных и местных } \\
\text { органах исполнительной власти - } \\
64 \text { до } 83 \\
\text { [Секретариата } \\
\text { Министров Украины] }\end{array}$ & $\begin{array}{l}\text { Эксперты - государственные служащие и } \\
\text { узкопрофильные специалисты, } \\
\text { общественные организации. } \\
\mathbf{3} \text { тип - «ручные» (провластные) } \\
\text { общественные организации. }\end{array}$ & $\begin{array}{l}\text { Усиление влияния общих консультаций и } \\
\text { рекомендаций для учета в деятельности } \\
\text { органов власти }\end{array}$ \\
\hline & 2010 & $\begin{array}{l}\text { При органах исполнительной } \\
\text { власти - } 71, \text { из которых при при } \\
\text { центральных органах } \\
\text { исполнительной власти - } 51 \\
\text { (всего центральных органов } \\
\text { исполнительной власти - 63). }\end{array}$ & $\begin{array}{l}\text { Эксперты - государственные служащие и } \\
\text { узкопрофильные специалисты, } \\
\text { провластные общественные организации, } \\
\text { независимые общественные организации, } \\
\text { с привлечением СМИ. } \\
4 \text { тип - «независимые» общественные } \\
\text { организации. }\end{array}$ & $\begin{array}{l}\text { Процедура предоставления органами } \\
\text { исполнительной власти информации о } \\
\text { решениях, принятых по результатам } \\
\text { рассмотрения предложений и замечаний } \\
\text { общественных советов; обязательное } \\
\text { создание на официальном веб-сайте } \\
\text { органов исполнительной власти рубрики } \\
\text { «Общественный совет». }\end{array}$ \\
\hline
\end{tabular}

${ }^{35}$ Громадські ради: створення та організаиія роботи. Довідково-методичний посібник для иленів громадських рад, за заг. ред. А.С. Крупника, Одеса $2012,326 \mathrm{c}$. 


\begin{tabular}{|c|c|c|c|c|}
\hline $\begin{array}{l}\text { Гражданская } \\
\text { экспертиза }\end{array}$ & $\begin{array}{l}2008- \\
2011\end{array}$ & $\begin{array}{l}\text { Улучшение государственной } \\
\text { политики в определенной сфере } \\
\text { или качества административных } \\
\text { услуг, предоставляемым } \\
\text { гражданам. }\end{array}$ & $\begin{array}{l}\text { Субъекты гражданской экспертизы: } \\
\text { гражданские организации, } \\
\text { профессиональные и творческие советы, } \\
\text { благотворительные, религиозные } \\
\text { организации, органы самоорганизации } \\
\text { населения, негосударственные СМИ, } \\
\text { другие непредпринимательские } \\
\text { объединения; ведущие ученые и } \\
\text { общественные деятели, специалисты, } \\
\text { лица, принимающие участие в изучении } \\
\text { общественного мнения }\end{array}$ & $\begin{array}{l}\text { Антикоррупционная экспертиза проектов } \\
\text { актов (2008); } \\
\text { организация общественных мероприятий } \\
\text { для обсуждения актуальных вопросов } \\
\text { развития отрасли или административно- } \\
\text { территориальной единицы (2011); } \\
\text { экспертиза проектов нормативно-правовых } \\
\text { актов по правам и свободам человека и } \\
\text { гражданина, по полномочиям органов } \\
\text { публичной власти и уполномоченных лиц; } \\
\text { предоставления административных услуг; } \\
\text { распределения и расходования средств } \\
\text { государственного бюджета и местных } \\
\text { бюджетов; конкурсных (тендерных) } \\
\text { процедур; других вопросов, которые могут } \\
\text { привести к противоправному получению } \\
\text { благ, услуг, льгот, других преимуществ } \\
\text { материального и/или нематериального } \\
\text { характера (2015) }\end{array}$ \\
\hline $\begin{array}{l}\text { Гражданский } \\
\text { контроль }\end{array}$ & $\begin{array}{l}2011- \\
2015\end{array}$ & $\begin{array}{l}\text { Соблюдение подконтрольными } \\
\text { объектами определенных } \\
\text { социальных норм; выполнение } \\
\text { ими социальных заданий, } \\
\text { непосредственно связанных с } \\
\text { защитой и реализацией прав и } \\
\text { свобод граждан; удовлетворение } \\
\text { их социальных нужд и интересов } \\
\end{array}$ & $\begin{array}{l}\text { Субъекты гражданского контроля: } \\
\text { отдельные граждане и их объединения. } \\
\text { Формы контроля: } \\
1 \text { тип - гражданский мониторинг; } \\
2 \text { тип - гражданская оценка }\end{array}$ & $\begin{array}{l}\text { Объекты гражданского контроля: органы } \\
\text { государственной власти, органы местного } \\
\text { самоуправления, государственные и } \\
\text { коммунальные предприятия, учреждения и } \\
\text { организации, а также негосударственные } \\
\text { субъекты разных организационно-правовых } \\
\text { форм, отдельные лица }\end{array}$ \\
\hline Лоббирование & $\begin{array}{l}2009- \\
2015\end{array}$ & $\begin{array}{l}\text { Легитимное влияние } \\
\text { зарегистрированных и } \\
\text { аккредитованых в установленном } \\
\text { порядке лиц (лоббистов и } \\
\text { лоббистских объединений) в } \\
\text { интересах заказчиков на органы } \\
\text { государственной власти, их } \\
\text { должностных и служебных лиц } \\
\text { во время принятия ими (участия в } \\
\text { принятии) нормативно-правовых } \\
\text { актов. }\end{array}$ & $\begin{array}{l}\text { Профессиональные лоббисты, } \\
\text { лоббистские объединения, деятельность } \\
\text { которых направлена на реализацию как } \\
\text { легитимных, так и нелегитимных } \\
\text { интересов путем целенаправленного } \\
\text { влияния на органы государственной } \\
\text { власти, их должностных и служебных лиц } \\
\text { с целью принятия социально } \\
\text { небходимых нормативно-правовых } \\
\text { актов }\end{array}$ & $\begin{array}{l}\text { Функцию организационного упорядочения } \\
\text { плюрализма общественных интересов; } \\
\text { Трансформация в группы политического } \\
\text { влияния неформального характера через } \\
\text { создание политических проектов вне } \\
\text { политических платформ, идеологий и } \\
\text { официальных форм общественного } \\
\text { воздействия на принятие общественно } \\
\text { важных решений. }\end{array}$ \\
\hline
\end{tabular}




\section{5. КОНСУЛЬТАТИВНО-СОВЕЩАТЕЛЬНЫЕ ОРГАНЫ (ОБЩЕСТВЕННЫЕ СОВЕТЫ)}

Впервые качественно-новые механизмы реализации конституционного права граждан на участие в управлении государственными делами, проведение органами исполнительной власти консультаций с общественностью и создание общественных советов при всех центральных и местных органах исполнительной власти было нормативно закреплено в 2004 году. С целью выполнения Указа Президента Украины от 31.07.2004 г № 854 «Об обеспечении условий для более широкого участия общественности в формировании и реализации государственной политики» Кабинет Министров Украины выдал постановление от 15.10.2014 № 1378 «Некоторые вопросы обеспечения участия общественности в формировании и реализации государственной политики». Постановлением было утверждено Типовое положение об общественном совете при центральном, местном органе исполнительной власти, что свидетельствует о попытках унифицировать и предложить универсальную однотипную консультативную форму для всех видов органов власти, при этом выяснились и границы, и меры, и формы, и даже определились субъекты влияния. Четко зафиксированное и ограниченное по мере воздействия на властные органы влияние гражданских объединений позволило политическим представителям власти стать манипулятором и производить отбор лояльных, но не всегда конструктивных, некритически настроенных активистов по «своим» критериям. Руководству органов исполнительной власти также позволялось возглавлять общественные советы. Соответственно, весь процесс организации работы советов и подготовки их заседаний стал зависеть от «доброй воли» руководителей, одновременно занимавших и должности руководителей общественных советов. Кроме того, Типовое положение об общественном совете не определяло порядок рассмотрения органами исполнительной власти решений общественных советов и отчетности по его результатам.

На практике оказалось, что этот документ, при всех его преимуществах и благих намерениях, имеет существенные недостатки, препятствующие эффективной деятельности создаваемых общественных советов. В постановлении были определены достаточно ограниченные полномочия общественных советов, сводившиеся только к координации мероприятий, связанных с созданием условий для проведения органами исполнительной власти консультаций с общественностью. Также не был разработан конкретный механизм формирования общественных советов. На практике, чаще всего, состав совета определял руководитель органа исполнительной власти по своему разумению, в других случаях - после предварительной аккредитации общественных организаций, изъявивших желание делегировать своих представителей в состав общественного совета. Это приводило к частым изменениям в персональном составе совета при назначении нового руководства органа.

В 2005 году в соответствии с постановлением Кабинета Министров Украины от 18.05.2005 г. № 356 «О дополнительных мероприятиях по привлечению граждан к участию в управлении государственными делами», принятом без обсуждения с общественностью, общественные советы были преобразованы в общественные коллегии при руководстве органов исполнительной власти. Такие изменения 
вызвали серьезную критику со стороны общественности. Общественные советы, по сути, становились «карманными» структурами органов власти и их состав часто менялся в зависимости от отношения властных структур и политической конъюктуры. Порядок формирования общественных советов предполагал вхождение в их состав только представители общественных организаций. Например, члены общественных советов при центральных органах исполнительной власти должны были избираться рейтинговым голосованием за кандидатов во время ежегодных собраний не менее чем одной четвертью от общего количества зарегистрированных общественных организаций. А члены советов при местных органов исполнительной власти - на собраниях не менее чем четвертью от количества зарегистрированных в соответствующем регионе общественных организаций. В результате введения нового порядка и малочисленности общественных советов в 2009-2010 годах соответствующие собрания всеукраинских общественных организаций уже не проводились.

В 2009 г. Кабинет Министров Украины, опять же без обсуждения с общественностью, принял постановление № 1302 от 26.11 .2009 г. «О дополнительных мероприятиях по обеспечению участия общественности в формировании и реализации государственной политики», которым снова отменялось постановление № 1378 и утверждалось Общее положение об общественных советах при центральных и местных органах исполнительной власти. Положительным последствием этого решения стало расширение полномочий общественных советов. Помимо права участия в мероприятиях, связанных с проведением органом исполнительной власти консультаций с общественностью, общественный совет получил возможность вносить предложения по усовершенствованию деятельности органов исполнительной власти, при котором она создана. Разработка предложения по вопросам, касающимся общественноэкономического развития государства и интересов широких слоев населения, защиты прав и свобод гражданина и общественных объединений, реализации политической реформы, формирования стратегий национальной безопасности, разработки отраслевых и региональных программ, участия граждан в формировании и реализации государственной политики, обеспечения прозрачности и открытости деятельности органов исполнительной власти, повышения квалификации государственных служащих вошли в сферу их внимания. Им было позволено проводить общественную экспертизу проектов нормативно-правовых актов, разрабатываемых органами исполнительной власти, при котором созданы, и подавать по её результатам предложения и замечания. При этом функция общественного контроля за эффективностью работы органов исполнительной власти охватывала в том числе и контроль за тем, насколько учитываются предложения и замечания общественности органом власти.

В то же время некоторые органы исполнительной власти создали общественные советы на основе Общего положения об общественных советах, утвержденного постановлением Кабинета Министров Украины от 26.11.2009 г. № 1302, не придерживаясь заложенного в нем механизма формирования общественных советов. Общественность встретила этот факт негативно, о чем свидетельствовали многочисленные жалобы в адрес правительства и судебные иски. В связи с этим постановлением от 03.11.2010 г. №996 «Об обеспечении участия общественности в формировании и реализации государственной политики» Кабинет Министров 
Украины отменил этот акт и утвердил новое Типовое положение об общественных советах при центральных и местных органах исполнительной власти.

Этот новый документ предусматривал избрание членов общественных советов путем рейтингового голосования во время собраний представителей институтов гражданского общества, заявивших о желании принимать участие в его работе. Полномочия общественных советов по новому Положению были существенно расширены. В частности, общественный совет получил возможность подавать органу, при котором он создан, обязательные к рассмотрению предложения по подготовке проектов нормативно-правовых актов по вопросам формирования и реализации государственной политики в соответствующей сфере, усовершенствования работы органа. Также Общественная антикоррупционная экспертиза проектов нормативно-правовых актов; общественный контроль за соблюдением нормативно-правовых актов, направленных на предупреждение и противодействие коррупции; сбор, обобщение предложений общественных организаций, имеющих важное общественное значение; организация общественных мероприятий для обсуждения актуальных вопросов развития отрасли или административно-территориальной единицы также возлагалась на общественные советы.

С целью «услышать» общественного мнение в процессе подготовки и организации выполнения решений Кабинета Министров Украины дважды в год должны были проводиться встречи руководителей общественных советов с Премьер-министром и членами правительства. Предусматривалось, что общественные советы при органах исполнительной власти будут формироваться по новому порядку в течение трех месяцев с дня опубликования постановления (до 11.02.2011г). До этого времени должны были функционировать предыдущие общественные советы. Постепенно консультативно-совещательные органы стали мощным инструментом влияния институтов гражданского общества на формирование и реализацию государственной политики.

Как свидетельствуют результаты общенационального мониторинга реализации в 2009 г. Концепции содействия органами исполнительной власти развитию гражданского общества работа общественных советов была признана одной из наиболее популярных и системных форм взаимодействия органов исполнительной власти с институтами гражданского общества. Исследование проводилось Консорциумом неправительственных организаций в составе Украинского независимого центра политических исследований, Творческого объединения «ТОРО» и Восточноукраинским центром гражданских инициатив.

\section{6. ГРАЖДАНСКАЯ ЭКСПЕРТИЗА}

Предметом гражданской экспертизы обычно является степень соблюдения законных интересов, прав и свобод граждан, соответствие принятых или принимаемых актов законодательству, потребностям и интересам жителей, социальные последствия действующих актов органов власти либо возможные социальные последствия проектов этих актов ${ }^{36}$. Полученные путем публичного

\footnotetext{
${ }^{36}$ Громадський контроль, Енциклопедія державного управління: у 8-ми т., Т. 1., редкол.: В.М. Князєв (співголова), І.В. Розпутенко (співголова) та ін., НАДУ, К. 2011, с. 113.
} 
обсуждения или опосредовано путем изучения этого мнения результаты гражданской экспертизы обязательно рассматриваются и учитываются в деятельности органов публичной власти, в частности при подготовке программ, формировании бюджетов, решении кадровых и организационных вопросов.

При планировании и проведении гражданской экспертизы следует руководствоваться Постановлением Кабинета Министров Украины от 5 ноября 2008 г. № 976 «Порядок содействия проведению гражданской экспертизы деятельности органов исполнительной власти». Также представителями активной общественности разработаны Интернет-ресурсы для желающих научиться проводить гражданскую экспертизу: «Рабочий стол общественного эксперта» (www.civicexpert.in.ua); «Ресурсный центр ГУРТ» (http:/gurt.org.ua/); Творческое объединение ТОРО (http://toro.org.ua/). Украинским независимым центром политических исследований выдано пособие «Гражданская экспертиза деятельности органов власти: шаг за шагом», в котором представлен алгоритм проведения общественной экспертизы и приведены примеры типовых документов (запросы, жалобы, исковые заявления) ${ }^{37}$. Антикоррупционная экспертиза проектов актов на предмет наличия в них положений, которые содействуют или могут содействовать совершению коррупционных правонарушений, проводится с целью предупреждения возникновения условий для совершения коррупционных правонарушений и разработки рекомендаций по их устранению. При совершении антикоррупционной гражданской экспертизы проектов нормативно-правовых актов, следует руководствоваться процедурными нормами проведения гражданской экспертизы деятельности органов исполнительной власти, установленными уже упоминаемым Постановлением Кабинета министров Украины от 5 ноября 2008 г. № 976 «Порядок содействия проведению общественной экспертизы деятельности органов исполнительной власти».

Заданиями экспертизы проектов нормативно-правовых актов являются:

1) выявление коррупциогенных норм (факторов, которые могут содействовать совершению коррупционных правонарушений);

2) подготовка предложений и рекомендаций по устранению в проектах нормативно-правовых актов коррупциогенных факторов;

3) включение в проекты нормативно-правовых актов превентивных антикоррупционных норм (положений, направленных на предупреждение коррупционных правонарушений).

\section{7. ГРАЖДАНСКИЙ КОНТРОЛЬ}

Гражданский контроль представляет собой гражданскую оценку степени выполнения органами власти и другими подконтрольными объектами их социальных задач, соблюдения определенных социальных норм. Характерные отличия гражданского контроля от других видов контроля состоят в том, что, вопервых, гражданский контроль совершается именно общественностью (организованной и неорганизованной); и речь идет о соблюдение подконтрольными объектами определенных социальных норм; выполнение ими социальных заданий,

\footnotetext{
${ }^{37}$ М.В. Лациба, Громадська експертиза діяльності органів виконавчої влади: крок за кроком, М. Лациба, О. Хмара, О. Орловський, Укр. незалеж. центр політ. дослідж, [Агентство “Україна”], К. 2010, 96с
} 
непосредственно связанных с защитой и реализацией прав и свобод граждан ${ }^{38}$. В качестве критериев для проведения гражданского контроля выбирают правовые (прописанные) и этические (неписанные) нормы и общественные ценности, которые используются в качестве эталонов при оценке деятельности объектов контроля и её результатов.

Как правило, гражданский контроль реализуется в двух формах:

1. Гражданский мониторинг - исследование какого-то явления или процесса, проводимого систематично (через определенный отрезок времени) по той же теме с использованием тех же инструментов. Гражданский мониторинг непрерывный процесс.

2. Гражданская оценка - это тщательное независимое измерение законченной деятельности либо деятельности, которая еще ведется, с целью определения степени достижения поставленных целей. Гражданская оценка всегда ограничена во времени ${ }^{39}$.

Важнейшим условием эффективности гражданского контроля является открытость и прозрачность деятельности органов власти, в частности, путем доступа к информации о деятельности этих органов, коммунальных и других предприятий, учреждений и организаций через Интернет.

\section{8. ЛОББИРОВАНИЕ}

Одним из устоявшихся и распространенных во многих демократических государствах механизмов целенаправленного влияния общественности на органы государственной власти во время принятия ими нормативно-правовых актов является лоббирование. В Украине лоббирование в большинстве случаев рассматривается как внеправовая деятельность, не отвечающая его природе. Однако, попытки легализировать следует отметить отдельно. Распоряжением Кабинета Министров Украины от 22 апреля 2009 г. № 448-р была согласована Концепция проекта Закона Украины «О влиянии общественности на принятие нормативно-правовых актов», который не получил поддержки в парламенте даже как идея.

Основная мысль документа заключалась в следующем. Лоббисты и лоббистские объединения выполняют важную функцию посредников между гражданами, институтами гражданского общества, субъектами хозяйствования и органами государственной власти, информируя выше названные органы об интересах разных социальных групп населения, состоянии дел в разных сферах общественной жизни. Согласно Концепции лоббирование - это легитимное влияние зарегистрированных и аккредитованных в установленном порядке лиц (лоббистов и лоббистских объединений) в интересах заказчиков на органы государственной власти, их должностных и служебных лиц во время принятия ими (участия в принятии) нормативно-правовых актов. Лоббирование выполняет функцию организационного упорядочения плюрализма общественных интересов. Одним из принципов лоббистской деятельности, помимо, прозрачности, подотчетности, является принцип порядочности - запрета составления субъектами лоббистской

\footnotetext{
${ }^{38}$ Громадський контроль..., с. 113.

${ }^{39}$ Европейская хартия активной гражданственности, http://eurobelarus.info/eaea/.
} 
деятельности договора о предоставлении лоббистских услуг с лицами, конкурирующими с их заказчиками, а также разглашение информации с ограниченным доступом, ставшей известной субъекту.

Лоббирование как профессиональная деятельность должна бы осуществляться такими методами, как:

1) подготовка и распространение предложений о необходимости принятия нормативно-правовых актов, информационно-аналитических материалов, результатов социологических и других исследований по вопросам, являющимся предметом регулирования нормативно-правовых актов; участие в разработке проектов нормативно-правовых актов.

2) контакты лоббиста с должностными лицами органов государственной власти, народными депутатами Украины, их помощниками - консультантами (телефонные разговоры, пересылка почтой (электронной почтой) заявлений, жалоб и предложений, телеграфных или факсимильных сообщений, личный прием);

3) участие в публичных мероприятиях, проводимых органами государственной власти;

4) организация и проведение публичных мероприятий (круглых столов, конференций, семинаров) с участием должностных лиц органов государственной власти, в которых они аккредитованы, и общественности;

5) размещение в СМИ комментариев специалистов, результатов исследований, опросов, аналитических материалов и др.;

6) другие, не запрещенные законодательством, действия, которые могут повлиять на позицию должностных лиц органов государственной власти, по вопросам, являющимся предметом регулирования нормативно-правовых актов.

Как результат, украинская реальность гражданского участия вышла не только на двойной монолог сторон, которые не слышат друг друга, но и на системные уровни, официального и неофициального взаимодействия - внутренний и внешний контуры системы государственного управления ${ }^{40}$. При этом внутрисистемный аспект взаимодействия субъектов разработки проектов управленческих решений приобрел доминантный характер, ориентированный на удовлетворение потребностей самой системы и людей в ней, и при ней, игнорируя внешний системный контур общественной и гражданской поддержки особенно важный в условиях кардинальных социально-экономических реформ.

\section{9. ВЫВОДЫ}

Взаимодействие органов публичного управления и институтов гражданского общества содействует развитию механизмов гражданского участия в принятии и реализации управленческих решений и способствует формированию ключевых моментов существования государственности - кредита и порога доверия граждан своему государству. Доверие к государственной власти измеряется, с одной стороны, степенью её поддержки гражданами, а с другой - тем, насколько граждане подчиняются её законам. Вместе с тем, представители государственной власти несут ответственность перед обществом, не только влияя на него, но и находя

\footnotetext{
40 О.В. Антонова, Середовище вироблення державної політики (теоретико-методологічні аспекти), автореф. дис. к-та наук з держ. упр., 25.00.01, ДРІДУ НАДУ при Президентові України, Д. 2005, 20 с.
} 
компромисс с ведущими группами общества в правовом воспитании и определении приоритетов в развитии общества. Реализация этого задания возможна при условии эффективного общественного контроля за принятием управленческих решений. Общественное влияние на формирование государственно-управленческих решений реализуется через консультативно-согласовательные органы (общественные советы), общественную экспертизу, общественный контроль, лоббирование. В процессе становления института общественных советов законодательная база, регламентирующая их действия, претерпела многочисленные изменения. Стоит отметить, что общественность отстояла наиболее приемлемый и демократический вариант положения об общественных советах, что в современном украинском обществе уже является подтверждением пробуждения гражданского общества. Активное использование разных форм общественного влияния на формирование государственно-управленческих решений содействует трансформации государственной службы Украины в высокопрофессиональный институт гражданского служения ${ }^{41}$.

\section{ЛИТЕРАТУРА}

[1] Конституція України: прийнята на п'ятій сесії Верховної Ради України 28 черв. 1996 р., зі змінами згідно Закону України від 21 лютого 2014/742, Відомості Верховної Ради України, К. 2014/11, с. 143.

[2] Стратегія сталого розвитку «Україна - 2020»: Указ Президента України від 12 січня 2015 p. № 5/2015, http://www.president.gov.ua/documents/18688.html.

[3] Антонова О.В., Середовище вироблення державної політики (теоретико-методологічні аспекти), автореф. дис. к-та наук 3 держ. упр., 25.00.01, ДРІДУ НАДУ при Президентові України, Д. 2005, 20 с.

[4] Артеменко Н.Ф., Управління професіоналізачією кадрів державної служби Украйни, автореф. дис. к-та наук з держ. упр., 25.00.03, ДРІДУ НАДУ при Президентові України, Д. 2010, 23 c.

[5] Баштанник В.В., Трансформачія державного управління в контексті європейських інтеграчійних прочесів: монографія, ДРІДУ НАДУ, Д. 2010, 390 с.

[6] Василевська Т.Е., Етичні виміри громадянськості державного службовия, „Публічне управління: теорія та практика” 5/1(2011), http://www.kbuapa.kharkov.ua/ebook/putp/2011-1/doc/3/05.pdf.

[7] Газарян С.В., Професіоналізація служби в органах місиевого самоврядування: зміст, форми та методи, автореф. дис. д-ра наук з держ. упр., 25.00.03, НАДУ при Президентові України, К. 2011, 39 с.

[8] Гончарук Н.Т., Управління керівним персоналом у сфері державної служби Украӥни: теорія та практика: монографія, ДРІДУ НАДУ, Д. 2012, 343 с.

[9] Громадський контроль, Енциклопедія державного управління: у 8-ми т., Т. 1., редкол.: В.М. Князєв (співголова), І.В. Розпутенко (співголова) та ін., НАДУ, К. 2011, с. 113.

[10] Громадські ради: створення та організація роботи. Довідково-методичний посібник для членів громадських рад, за заг. ред. А.С. Крупника, Одеса 2012, 326 с.

[11] Державна служба в иифрах - 2015: Інформачійне видання Центру адаптаиї державної служби до стандартів ЄС, Прес-центр, http://www.center.gov.ua/prestsentr/materiali/item/1356-86\%D0\%B8\%D1\%84\%D1\%80\%D0\%B0\%D1\%85-2013.

\footnotetext{
${ }^{41}$ Т.Е. Василевська, Етичні виміри громадянськості державного службовия, „Публічне управління: теорія та практика" 5/1(2011), http://www.kbuapa.kharkov.ua/e-book/putp/2011-1/doc/3/05.pdf. Назва 3 екрану.
} 
[12] Европейская хартия активной гражданственности, http://eurobelarus.info/eaea/.

[13] Енцииклопедичний словник з держсавного управління, уклад.: Ю.П. Сурмін, В.Д. Бакуменко, А.М. Михненко та ін.; за ред. Ю.В. Ковбасюка, В.П. Трощинського, Ю.П. Сурміна, НАДУ при Президентові України, К. 2010, 820 с.

[14] Енциклопедія державного управління, у 8 т., Нац. акад. держ.упр. при Президентові України, наук.ред. колегія: Ю.В. Ковбасюк (голова) та ін., К. 2011.

[15] Ефективна організація роботи громадської ради: методичні рекомендації, www.gromrady.org.ua/2011/06/posibnyk-efektyvna-orhanizatsiya-roboty-hromadskoji-radymetodychni-rekomendatsiji.

[16] Кошова Т.В., Професійний розвиток державних службовиів на засадах самотренінгу, автореф. дис. к-та наук з держ. упр., 25.00.03, ДРІДУ НАДУ при Президентові України, Д. 2004, 22 с.

[17] Крутій О.М., Діалогова взаємодія органів влади та громадськості як умова демократизаиії державного управління, автореф. дис. ... д-ра наук 3 держ.упр., 25.00.02, О.М. Крутій; Нац. акад. держ. упр. при Президентові України, Харк. регіон. інт держ. упр., Х. 2010, 36 с.

[18] Кучабський О., Довіра до органів публічної влади як ключовий фактор ефективності системи державного управління, О. Кучабський, С. Погорєлий, „Публічне управління: теорія та практика” 13/1 (2013), http://kbuapa.kharkov.ua/e-book/putp/2013-1/doc/2/07.pdf.

[19] Кушнірова Г.П., Формування професійної компетентності посадових осіб місиевого самоврядування, автореф. дис. к-та наук з держ. упр., 25.00.03, НАДУ при Президентові України, К. 2011, 23 с.

[20] Лациба М.В., Громадська експертиза діяльності органів виконавчої влади: крок за кроком, М. Лациба, О. Хмара, О. Орловський, Укр. незалеж. центр політ. дослідж, [Агентство "Україна"], К. 2010, 96 с.

[21] Лісєєнко О., Динаміка політичного капіталу в Україні, „Політичний менеджмент” 10/1 (2005), c. 90-96.

[22] Лукашевич О.М., Громадянськість як результат громадянського розвитку особистості: психологічний дискурс, [в:] О.М. Лукашевич, Збірник наукових прачь $K$ ПНУ імені І.Огієнка, Інституту психології ім. Г.С.Костюка НАПН України. Проблеми сучасної психології, 2014, Випуск 24, с. 467-477

[23] Морально-етичні засади розвитку державної служби Украӥни: європейський та вітчизняний досвід: монографія, С.М. Серьогін, О.В. Антонова, І.І. Хожило та ін.; за заг. ред. проф. С.М. Серьогіна, ДРІДУ НАДУ, Д. 2007, 272 с.

[24] Нинюк I.I., Професіоналізм держсавних службовців: сутність, стан та особливості формування, автореф. дис. к-та наук з держ. упр., 25.00.03, НАДУ при Президентові України, К. 2005, 18 с.

[25] Ничта Н.Л., Психологічний ресурс оптимізації взаємодії місиевих органів виконавчої влади з громадськістю, автореф. дис. ... канд.. наук з держ.упр., 25.00.02, Нац. акад. держ. упр. при Президентові України, Львів. регіон. ін-т держ. упр., Л. 2014, 21 с.

[26] Пархоменко-Куцевіл О.I., Формування, розвиток та модернізачія державних посад: конщептуально-методологічні засади: монографія, ФАДА, ЛТД, К. 2010, 296 с.

[27] Петренко О.С., Формування інтегрованого інституту публічної служби в Украӥні, автореф. дис. к-та наук з держ. упр., 25.00.03, Петренко Оксана Станіславівна; ДРІДУ НАДУ при Президентові України, Д. 2008, 20 с.

[28] Реформування професійного навчання державних службовиів в Украӥні: проблеми та перспективи ДРІДУ НАДУ, колект. моногр. С.М. Серьогін, Є.І. Бородін, Н.А. Липовська, І.І. Хожило [та ін.]; за заг. та наук. ред. С.М. Серьогін, ДРІДУ НАДУ, Д. $2012,274 \mathrm{c}$.

[29] Сидоренко Н.С., Формування професійної культури державних службовиів, автореф. дис. к-та наук з держ. упр., 25.00.03, Сидоренко Павло Володимирович, НАДУ при Президентові України, К. 2012, 23 с. 
[30] Синергетичні засади державного управління в умовах реформ: монографія, С.М. Серьогін, І.В. Письменний, I.I. Хожило та ін..; за заг. ред. С.М. Серьогіна, ДРІДУ НАДУ, Д. 2007, 194 с.

[31] Украйнське суспільство 1992-2012. Стан та динаміка змін. Соиіологічний моніторинг, За ред. д. ек. н. В. Ворони, д. соц. н. М. Шульги, Інститут соціології НАН України, К. 2012, 660 c, http://i-soc.com.ua/institute/soc-mon-2012.pdf.

[32] Моніторинг громадської думки, Український інститут соціологічних досліджень ім. О.Яременка, http://www.uisr.org.ua/monitoring.

[33] Довіра до соиіальних інституиій та групп: за матеріалами прес-релізу Ліана Новіковой (по состоянию на 4-14 декабря 2015), Київський міжнародний інститут соціології, $\mathrm{http}: / / \mathrm{www} \cdot \mathrm{kiis} \cdot \mathrm{com} \cdot \mathrm{ua} /$ ?lang=ukr\&cat=reports\&id=579\&page $=2 \& \mathrm{t}=3$.

[34] Довіра до політичних інститутів та банків падає, компанії повертають довіру громадян (GfK Ukraine), http://sostav.ua/news/2009/04/22/8/19934/.

[35] Філіпова Т.В., Професійний менталітет державних службовиів в Украйні: технологія формування, автореф. дис. к-та наук 3 держ. упр., 25.00.03, ДРІДУ НАДУ при Президентові України, Д. 2006, 20 с.

[36] Цегольник П.А., Формування професійної моделі фахівия в сфері управління, автореф. дис. к-та наук з держ. упр., 25.00.03, НАДУ при Президентові України, К. 1997, 17 с.

[37] Чабанна М.В., Довіра до політичних інститутів: передумови та наслідки для демократії, Магістеріум, К. 2014, Вип. 58, с. 8-14.

[38] Шпекторенко І.В., Управління професійною мобільністю державних службовиів, автореф. дис. д-ра наук з держ. упр., 25.00.03, Інститут з-тва Верховної Ради України, К. 2012, $32 \mathrm{c}$.

[39] Jurgilewicz M.K., Kilka uwag na temat znaczenia pojecia administracji publicznej, M.K. Jurgilewicz, O. Jurgilewicz, M. Ura, „Modern Management Review”21/2 (2014), c. 43-52.

[40] Newton K., Political trust and institutional performance, [в:] K. Newton, Social and Political Trust, European Social Survey, 2013, http://essedunet.nsd.uib.no/cms/topics/2/3/all.html.

[41] Peffley M., Democratization and Political Tolerance in Seventeen Countries: A Multi-level Model of Democratic Learning, „Political Research Quarterly” 56/3 (2003), c. 243-257.

\section{TOOLS OF CITIZENS' IMPACT ON THE DEVELOPMENT OF PUBLIC SERVICE IN UKRAINE}

This article is devoted to the tools of civic influence on the public service development as a humanizing factor for Ukrainian society. The level of modern civil society's activity is analyzed, accounting its transformation under the social and political changes in Ukraine. The main approaches to interpretation of civic influence on public service development are generalized. A concept "public control after the public policy-making and decision-making" is examined. There were considered the significant tools of civic influence on forming the public policy and decision-making, among of which are consultative and conciliatory councils, public control (public monitoring, public expertise), lobbying (administrative and parliament).

Becoming the consultative and conciliatory councils' institute is characterized by taking into account experience of acceptance of normative-legal documents, which regulate their activity, without a concordance with public. The value of public expertise is described for the activity's estimation of executive bodies, the expedience of decisions' acceptance and implementation by these authorities, the preparation of their proposals to normative-legal acts on rights and freedoms of man, terms of references of government and public administration officials.

The specific differences of public control from others tools of civic influence are researched and distinguished. It's mentioned, that public control is an inalienable element of 
forming the democratic, social, legal state in Ukraine, civic control system of democratic public administration, and irreplaceable constanta of society's development, that's providing a support to public relations in a state of stability and equilibrium.

Keywords: tools of civic influence, public service development, humanizing the public administration, public control, the public policy-making and decision-making

\section{DOI: 10.7862/rz.2016.mmr.1}

Tekst złożono w redakcji: maj 2016

Przyjęto do druku: czerwiec 2016 